\title{
Reframing Project Management Process Paralysis: An Autoethnographic Study of the UK Fire Service
}

\author{
Carl Barber ${ }^{a}$, Nicholas Dacre ${ }^{b}, \&$ Hao Dong ${ }^{b-}$
}

\author{
${ }^{a}$ Project Delivery and Improvement Team, UKRI, Swindon, Wiltshire, SN2 1FL, UK \\ ${ }^{\mathrm{b}}$ University of Southampton Business School, University of Southampton, Southampton, SO17 1BJ, UK \\ ${ }^{*}$ Corresponding Author: h.dong@soton.ac.uk
}

\begin{abstract}
The Covid-19 pandemic has created new social, environmental, and economic challenges for organisational routines, and a multilevel perspective of project management processes and decision making is required to untangle the complex nature of projects and phenomena. This research hence aims to investigate reframing of traditional project failure reasoning in pressurised situations by adopting a wider organisational view of the causation of failure using models from high-risk industries which support good decision-making practices and highlighting the project, programme and organisational structures which inherently position a project manager to fail in conditions with cognitive overload, limitations, and constraints. Through an institutional perspective, both individuals (the project managers) and organisations are considered under the influence of normative and cognitive pressures, and both are sources of change.
\end{abstract}

Keywords: Project Management, Autoethnography, Fire Service, UK, Process Paralysis, Covid-19, Institutional Theory.

\section{Citation}

Barber, C., Dacre, N., \& Dong, H. (2021). Reframing Project Management Process Paralysis: An Empirical Study of the UK Fire Service. Advanced Project Management, 21(6). https://dx.doi.org/10.2139/ssrn.3830416

\section{Introduction}

Projects are embedded in their institution fields, as well as interact with the institutions (Winch \& Maytorena-Sanchez, 2020). There have been many studies into the effect on decision making in high-risk industries such as those of aircraft pilots (Dacre et al., 2020) and Fire Service Incident Commanders. As a result, there have been theories and models created to try to prevent critical decision making from becoming compromised (Clarke \& Miles, 2012; O'Hare \& Smitheram, 1995; Okray \& Lubanau, 2004; Schriver et al., 2008; Williams-Bell et al., 2015), originally based on the work by Klein (2001) on naturalistic decision making and later reviewed and adapted, based on live incident decision making data, by Cohen-Hatton et al (2015). The UK Fire Service has developed a functional and effective decisionmaking model in an attempt to control situations that are often characterised as having low resource availability, either one or two key decision makers, high information inputs from multiple sources, short process times and a moral or life-threatening event that acts as both a motivator and a blocker to clear thought and planning. However, the Covid-19 pandemic has created new social, environmental, and economic challenges for organisational routines (Sonjit et al., 2021), and a multilevel perspective of project management processes and decision making is required to untangle the complex nature of projects and phenomena (Howard-Grenville, 2020; Müller \& Klein, 2020). 
This study therefore aims to investigate reframing of traditional project failure reasoning in pressurised situations by adopting a wider organisational view of the causation of failure using models from high-risk industries which support good decision-making practices and highlighting the project, programme and organisational structures which inherently position a project manager to fail in conditions with cognitive overload (Dacre et al., 2020), limitations, and constraints. Through an institutional perspective (Dong et al., 2021), both individuals (the project managers) and organisations are considered under the influence of normative and cognitive pressures, and both are sources of change (Corbett et al., 2018; Dacin et al., 2002; DiMaggio \& Powell, 1983; Teo et al., 2003).

\section{Research Approach}

This research adopts an autoethnographic methodology, which is being applied in research on project and organisation topics (Addyman et al., 2020; Hsu et al., 2021; Pentland \& Feldman, 2008; Pink et al., 2013) to achieve in-depth understanding of the re-creation of patterns of actions through interview and ethnographic observation (Reynolds et al., 2019) combined with the researcher's personal longitudinal experience (Anderson, 2006; Jones et al., 2013).

Sourcing information directly from the first author's own experiences across high-risk incident command and business change project management roles, this paper outlines the potential benefits to both project professionals and organisations that could be realised through the application of decision making models and risk management strategies, typical of high-risk industry, at an organisational level as a means to alter the existing dynamics and institutional pressures in project management practices to enable project professionals to manage decision making in a more consistent evidence-based manner and reduce the risk of command indecision and project failure.

\section{Discussion \& Future Research}

Previously the symptoms of decision-making failure have been attributed to a more general experience of internalised stress which, this paper proposes, has worked to obfuscate the underlying causational factors at play and, in many cases, is a misapplied correlation of information. In other words, a project manager is effectively acting as a fuse in the system, and significant issues are only highlighted when they fail. It is this study's proposition that these models are equally applicable to environments where the moral or personal threat is less visible and time constraints are artificially created, as in the contexts of most non-emergency, life-saving projects, but remain a significant motivator, as in both situations, the decision maker reaches a point of saturation that either affects their ongoing decision making capabilities or cause them to freeze entirely, preventing any decision making from taking place, and that many people in their day to day occupation suffer from what is known as command indecision or 'Helmet burn' because of this (Beaton et al., 1999), leading to poor mental wellbeing and ineffective working practices, which are crucial to project success (Lindsjørn et al., 2016). The command indecision effect, if not addressed, continue to impact the individual project manager's ability to perform effectively and will have a cumulative degradation effect on all future decision making until the source of or sources of input acting on the decision maker have been removed.

Extant research has also used the factor of moral and life-threatening impetus to rationalise the short decision timeframes and the additional mental pressure this causes to separate decision making in these situations as distinct from everyday decision making, this study suggests that this is in many cases a facility and that the internal pressures upon project professionals can feel as real as those a firefighter would feel at an incident. In the example of the project manager, though it is mostly not the potential harm or loss of another individual's life that is faced as the result of a good or bad decision, they have to take responsibilities for important decision making for their projects (McAvoy \& Butler, 2009; Taylor, 2016), while facing a perceived threat to their own wellbeing or condition whether that pressure is felt like a direct threat to their bonus from an underperforming project or as a wider, more expansive corrupting threat of career-ending, financially bankrupting personal fears from underperformance in the eyes of the profession, employer or peers.

Project managers often need to play boundary spanners or institutional entrepreneurs (Aldrich \& Herker, 1977; Biesenthal et al., 2018; Uzzi, 1997). They need to deal with multiple tensions of projects and institutions 'arise as the shadow of the past 
(legacies of previous projects) and create tensions for continuity' (Uriarte et al., 2019, p. 321) and speak up for themselves and their project teams against institutional pressures (Corbett et al., 2018; Taylor, 2016). In this situation, deferring or passing that responsibility to another who may be in a better position to them make the judgement call is also likely to be delayed or prevented by the individual who feels personal or moral threat from the situation. Therefore, from a relational perspective (Garud \& Gehman, 2012), this research aims to look at how the structure and systems surrounding a project may cause the single point of failure (the project manager) to reach a point of failure by design, given that the identified causational relationship that a project professional who experiences stress is the cause of failure and reverse this relationship.

\section{References}

Addyman, S., Pryke, S., \& Davies, A. (2020). 'Re-Creating Organizational Routines to Transition Through the Project Life Cycle: A Case Study of the Reconstruction of London's Bank Underground Station'. Project Management Journal, 51(5), 522-537. https://doi.org/10.1177/8756972820943436

Aldrich, H., \& Herker, D. (1977). Boundary spanning roles and organization structure. Academy of Management Review, 2(2), 217-230.

https://doi.org/10.5465/amr.1977.4409044

Anderson, L. (2006). Analytic Autoethnography. Journal of Contemporary Ethnography, 35(4), 373-395.

https://doi.org/10.1177/0891241605280449

Beaton, R., Murphy, S., Johnson, C., Pike, K., \& Corneil, W. (1999). Coping Responses and Posttraumatic Stress Symptomatology in Urban Fire Service Personnel. Journal of Traumatic Stress, 12, 293-308. https://doi.org/10.1023/A:1024776509667

Biesenthal, C., Clegg, S., Mahalingam, A., \& Sankaran, S. (2018). Applying institutional theories to managing megaprojects. International Journal of Project Management, 36(1), 43-54.

https://doi.org/10.1016/j.ijproman.2017.06.006

Clarke, A., \& Miles, J. C. (2012). Strategic Fire and Rescue Service decision making using evolutionary algorithms. Advances in Engineering Software, 50, 29-36. https://doi.org/10.1016/j.advengsoft.2012.04.002
Cohen-Hatton, S. R., Butler, P. C., \& Honey, R. C. (2015). An Investigation of Operational Decision Making in Situ: Incident Command in the U.K. Fire and Rescue Service. Human Factors, 57(5), 793-804.

https://doi.org/10.1177/0018720815578266

Corbett, J., Webster, J., \& Jenkin, T. A. (2018).

Unmasking Corporate Sustainability at the Project Level: Exploring the Influence of Institutional Logics and Individual Agency. Journal of Business Ethics, 147, 261286. https://doi.org/10.1007/s10551-015-2945-1

Dacin, M. T., Goodstein, J., \& Scott, W. R. (2002). Institutional Theory and Institutional Change: Introduction to the Special Research Forum. Academy of Management Journal, 45(1), 45-56.

https://doi.org/10.2307/3069284

Dacre, N., Constantinides, P., \& Nandhakumar, J. (2014). Instantiation of Organisational Routines in CrossExpertise Collaborative Enterprise Systems.

International Symposium on Process Organization Studies, Rhodes, Greece.

https://dx.doi.org/10.2139/ssrn.3829127

Dacre, N., Kockum, F., \& Senyo, PK. (2020). Transient Information Adaptation of Artificial Intelligence: Towards Sustainable Data Processes in Complex Projects. British Academy of Management, Manchester, UK. https://dx.doi.org/10.2139/ssrn.3813559

DiMaggio, P. J., \& Powell, W. W. (1983). The iron cage revisited: Institutional isomorphism and collective rationality in organizational fields. American Sociological Review, 48, 147-160. https://doi.org/10.2307/2095101

Dong, H., Dacre, N., \& Bailey, A. (2021). Sustainable Agile Project Management in Complex Agriculture Projects: An Institutional Theory Perspective. Advanced Project Management, 21(3).

https://dx.doi.org/10.2139/ssrn.3829912

Garud, R., \& Gehman, J. (2012). Metatheoretical perspectives on sustainability journeys: Evolutionary, relational and durational. Research Policy, 41(6), 980995. https://doi.org/10.1016/j.respol.2011.07.009

Howard-Grenville, J. (2020). Grand Challenges, Covid 19 and the Future of Organizational Scholarship. Journal of Management Studies, 58(1), 254-258.

https://doi.org/10.1111/joms.12647

Hsu, MW., Dacre, N., \& Senyo, PK. (2021). Applied Algorithmic Machine Learning for Intelligent Project Prediction: Towards an AI Framework of Project Success. Advanced Project Management, 21(4).

https://dx.doi.org/10.2139/ssrn.3823900 
Jones, S. H., Adams, T. E., \& Ellis, C. (Eds.). (2013). Handbook of autoethnography. Routledge.

Klein, G. (2001). Sources of Power: How People Make Decisions. In Leadership and Management in Engineering (Vol. 1).

https://doi.org/10.1061/(ASCE)1532-6748(2001)1:1(21)

Lindsjørn, Y., Sjøberg, D. I. K., Dingsøyr, T., Bergersen, G. R., \& Dybå, T. (2016). Teamwork quality and project success in software development: A survey of agile development teams. The Journal of Systems and Software, 122, 274-286.

https://doi.org/10.1016/j.jss.2016.09.028

McAvoy, J., \& Butler, T. (2009). The role of project management in ineffective decision making within agile software development projects. European Journal of Information Systems, 18(4), 372-383.

https://doi.org/10.1057/ejis.2009.22

Müller, R., \& Klein, G. (2020). The COVID-19 Pandemic and Project Management Research. Project Management Journal, 51(6), 579-581.

https://doi.org/10.1177/8756972820963316

O’Hare, D., \& Smitheram, T. (1995). 'Pressing On' Into Deteriorating Conditions: An Application of Behavioral Decision Theory to Pilot Decision Making. The International Journal of Aviation Psychology, 5(4), 351370,. https://doi.org/10.1207/s15327108ijap0504_2

Okray, R., \& Lubanau, T. (2004). Crew Resource Management for the Fire Service. PennWell Corporation.

Pentland, B. T., \& Feldman, M. S. (2008). Issues in empirical field studies of organizational routines. In M. C. Becker (Ed.), Handbook of organizational routines (pp. 281-300). Edward Elgar Publishing.

Pink, S., Tutt, D., \& Dainty, A. (2013). Ethnographic research in the construction industry. Routledge.

Reynolds, D., \& Dacre, N. (2019). Interdisciplinary Research Methodologies in Engineering Education Research. Engineering Education Research Network, Coventry, UK. https://dx.doi.org/10.2139/ssrn.3812769
Schriver, A. T., Morrow, D. G., Wickens, C. D., \& Talleur, D. A. (2008). Expertise Differences in Attentional Strategies Related to Pilot Decision Making. Human Factors: The Journal of the Human Factors and Ergonomics Society, 50(6), 864-878. https://doi.org/10.1518/001872008X374974

Sonjt, P., Dacre, N., \& Baxter, D. (2021). Homeworking Project Management \& Agility as the New Normal in a Covid-19 World. Advanced Project Management, 21(5). https://dx.doi.org/10.2139/ssrn.3823901

Taylor, K. J. (2016). Adopting agile software development: The project manager experience. Information Technology \& People, 29(4), 670-687. https://doi.org/10.1108/ITP02-2014-0031

Teo, H. H., Wei, K. K., \& Benbasat, I. (2003). Predicting intention to adopt interorganizational linkages: An institutional perspective. MIS Quarterly, 27(1), 19-49. https://doi.org/10.2307/30036518

Uriarte, Y. T., DeFillippi, R., Riccaboni, M., \& Catoni, M. L. (2019). Projects, institutional logics and institutional work practices: The case of the Lucca Comics \& Games Festival. International Journal of Project Management, 37(2), 318-330.

https://doi.org/10.1016/j.ijproman.2018.09.001

Uzzi, B. (1997). Social Structure and Competition in Interfirm Networks: The Paradox of Embeddedness. Administrative Science Quarterly, 42(1), 35-67.

https://doi.org/10.2307/2393808

Williams-Bell, F. M., Murphy, B. M., Kapralos, B., Hogue, A., \& Weckman, E. J. (2015). Using Serious Games and Virtual Simulation for Training in the Fire Service: A Review. Fire Technology, 51, 553-584. https://doi.org/10.1007/s10694-014-0398-1

Winch, G. M., \& Maytorena-Sanchez, E. (2020). Institutional projects and contradictory logics: Responding to complexity in institutional field change. International Journal of Project Management, 38(6), 368-378.

https://doi.org/10.1016/j.ijproman.2020.08.004

Advanced Project Management | APROM www.southampton.ac.uk/aprom

The Advanced Project Management research series accepts working conceptual and empirical papers, literature reviews, development papers, technical papers, case studies, and general reviews. Papers of a qualitative, quantitative, or mixed methods nature are welcome, including highly novel research approaches where relevant. Authors retain copyright of their work. The title page should include: Title; Author Name(s); Institution Affiliation(s); Contact Email Address(es); Abstract; and Keywords. Submit your paper as a Word or PDF file to: aprom@southampton.ac.uk 